\title{
Identification of sorghum hybrids with high phenotypic stability using GGE biplot methodology
}

P.E. Teodoro ${ }^{1 *}$ J.E. Almeida Filho ${ }^{2}$, R.F. Daher ${ }^{3}$ C.B. Menezes ${ }^{4}$ M.J. Cardoso ${ }^{5}$, V.P.C. Godinho ${ }^{6}$, F.E. Torres ${ }^{7}$ and F.D. Tardin ${ }^{8}$

${ }^{1}$ Departamento de Biologia Geral, Universidade Federal de Viçosa, Viçosa, MG, Brasil

${ }^{2}$ Departamento de Estatística, Universidade Federal de Viçosa, Viçosa, MG, Brasil

${ }^{3}$ Centro de Ciências e Tecnologias Agropecuárias,

Universidade Estadual do Norte Fluminense Darcy Ribeiro,

Campos dos Goytacazes, RJ, Brasil

${ }^{4}$ Núcleo de Recursos Genéticos e Obtenção de Cultivares, Embrapa Milho e Sorgo, Sete Lagoas, MG, Brasil

${ }^{5}$ Setor de Produção Vegetal, Embrapa Meio Norte, Teresina, PI, Brasil

${ }^{6}$ Setor de Produção Vegetal, Embrapa Rondônia, Vilhena, RO, Brasil

${ }^{7}$ Departamento de Fitotecnia, Universidade Estadual do Mato Grosso do Sul, Aquidauana, MS, Brasil

${ }^{8}$ Núcleo de Recursos Genéticos e Obtenção de Cultivares,

Embrapa Milho e Sorgo, Sinop, MT, Brasil

*These authors contributed equally to this study.

Corresponding author: F.D. Tardin

E-mail: flavio.tardin@embrapa.com

Genet. Mol. Res. 15 (2): gmr.15027914

Received October 27, 2015

Accepted December 22, 2015

Published June 10, 2016

DOI http://dx.doi.org/10.4238/gmr.15027914

ABSTRACT. The aim of this study was to identify sorghum hybrids that have both high yield and phenotypic stability in Brazilian environments. Seven trials were conducted between February and March 2011. 
The experimental design was a randomized complete block with 25 treatments and three replicates. The treatments consisted of 20 simple pre-commercial hybrids and five witnesses of grain sorghum. Sorghum genotypes were analyzed by the genotype main effects + genotype environment interaction (GGE) biplot method if significant genotype $\mathrm{x}$ environment interaction, adaptability, and phenotypic stability were detected. GGE biplot methodology identified two groups of environments, the first composed of Água Comprida-MG, Montividiu-GO, and VilhenaRO and the second of Guaíra-SP and Sete Lagoas-MG. The BRS 308 and 1G282 genotypes were found to have high grain yield, adaptability, and phenotypic stability and are thus indicated for cultivation in the first and second groups of environments, respectively.

Key words: Genotypes x environment interaction; Grain sorghum; Sorghum bicolor

\section{INTRODUCTION}

Grain sorghum (Sorghum bicolor L.) is grown in several Brazilian regions with different soil and climatic conditions. This makes it difficult to recommend cultivars, since those adapted to growth under a specific condition do not exhibit superior performance under different environmental conditions. This differential response of genotypes in different environments is known as the genotype $\mathrm{x}$ environment interaction (GE), and when recommending sorghum cultivars in the face of GE, it is necessary to annually test a large number of genotypes in different environments before the final recommendation and multiplication is made (Almeida Filho et al., 2014). However, despite its importance, the simple GE interaction analysis does not provide complete and accurate information about the behavior of each genotype in various environmental conditions. It is also necessary to analyze adaptability and phenotypic stability (Ramalho et al., 2012; Cruz et al., 2014), enabling genotypes with predictable behavior and that are responsive to environmental variations in specific or broad conditions to be identified (Yates and Cochran, 1938). In this context, there are methodologies that adequately explain the main effects (genotypes and environments) and their interactions, such as GGE biplot analyzes (Miranda et al., 2009).

GGE biplot analysis generates a graph that is able to interpret the GE interaction in the site regression model (Yan et al., 2000). This model assumes that the main effect of the environment is not relevant in the selection of genotypes $(\mathrm{G})$, with the $\mathrm{G}$ effect presented as a multiplicative GE effect. The axes of the graphs represent the first two principal components in multivariate analysis, assuming that the effects of environments are fixed, and that other effects are random (Miranda et al., 2009). Thus, when selecting cultivars for recommendation, the adaptive capacity of genotypes is the most important factor when compared to the climatic and soil conditions, and the changes in the trait studied are due only to the G and GE effects (Yan et al., 2000).

Recently, GGE biplot methodology has been used to investigate the GE interaction for several crops; however, there have been no reports of its use for the grain sorghum. Therefore, the aim of this study was to identify grain sorghum genotypes grown in the second harvest of 2011, which simultaneously generate a high grain yield and demonstrate adaptability and stability to Brazilian environments of importance for the crop. 


\section{MATERIAL AND METHODS}

We conducted seven competition trials of grain sorghum cultivars between February and March 2011. The soil and climatic features of the different environments are shown in Table 1. The experimental design was a randomized complete block design with 25 treatments and three repetitions. The experimental unit consisted of four lines of $5 \mathrm{~m}$ in length, spaced 0.5 $\mathrm{m}$ between rows, and $0.1 \mathrm{~m}$ among plants within each line. In each experimental unit the grain yield was evaluated in two central rows, corrected to $13 \%$ moisture, and extrapolated to $\mathrm{kg} / \mathrm{ha}$.

Table 1. Climate and soil features of the seven evaluated environments.

\begin{tabular}{l|c|c|c|c|c|c}
\hline $\begin{array}{l}\text { Environments (Municipality- } \\
\text { State) }\end{array}$ & Abbreviation & Altitude $(\mathrm{m})$ & Latitude & Longitude & Average temperature $\left({ }^{\circ} \mathrm{C}\right)$ & Accumulated rainfall (mm) \\
\hline Água Comprida-MG & AC & 535 & $-20^{\circ} 03^{\prime}$ & $-48^{\circ} 06^{\prime}$ & 23.0 & 500 \\
\hline Guaíra-SP & GUA & 507 & $-20^{\circ} 19^{\prime}$ & $-48^{\circ} 19^{\prime}$ & 23.1 & 490 \\
\hline Montividiu-GO & MON & 833 & $-17^{\circ} 26^{\prime}$ & $-51^{\circ} 10^{\prime}$ & 23.2 & 700 \\
\hline Rio Verde-GO & RV & 754 & $-17^{\circ} 47^{\prime}$ & $-50^{\circ} 55^{\prime}$ & 23.1 & 720 \\
\hline Sete Lagoas-MG & SL & 773 & $-19^{\circ} 28^{\prime}$ & $-44^{\circ} 15^{\prime}$ & 22.1 & 400 \\
\hline Teresina-PI & TER & 81 & $-5^{\circ} 05^{\prime}$ & $-42^{\circ} 48^{\prime}$ & 28.4 & 1060 \\
\hline Vilhena-RO & VIL & 577 & $-12^{\circ} 44^{\prime}$ & $-60^{\circ} 08^{\prime}$ & 24.0 & 795 \\
\hline
\end{tabular}

The treatments involved 20 pre-commercial single-hybrids (144013, 307001, 307047, 307061, 307063, 307071, 307087, 307091, 307095, 307131, 307341, 307401, 307421, $307509,307511,307541,307561,307651,307671$, and 307689) and five commercial hybrids (1G282, BRS 308, BRS 330, BRS 373, and BR80) of grain sorghum.

Grain yield data were subjected to individual analysis of variance, with the effect of treatments considered fixed and all other effects considered random. The relationship between the largest and smallest mean square of the residue from individual analysis of variance did not exceed 7:1, allowing the joint analysis of trials to be implemented (Banzatto and Kronka, 2006). Subsequently, data were subjected to analysis of adaptability and stability using GGE biplot methodology (Yan et al., 2000).

The GGE biplot model used was:

$$
\mathrm{Y}_{\mathrm{ij}}-\mu-\beta_{\mathrm{j}}=\mathrm{y}_{1} \varepsilon_{\mathrm{i} i 1} \rho_{\mathrm{j} 1}+\mathrm{y}_{2} \varepsilon_{\mathrm{i} 2} \rho_{\mathrm{j} 2}+\varepsilon_{\mathrm{ij}} \quad \text { Equation } 1
$$

where $Y_{i j}$ is the mean grain yield of genotype $\mathrm{i}$ at environment $\mathrm{j} ; \mu$ is the overall mean of observations; $\beta_{j}$ is the main effect of the environment; $y_{1}$ and $y_{2}$ are the errors associated to first (PC1) and second principal component (PC2), respectively; $\varepsilon_{1}$ and $\varepsilon_{2}$ are the values of $\mathrm{PC} 1$ and $\mathrm{PC} 2$, respectively, for the genotype of order $\mathrm{i} ; \rho_{j 1}$ and $\rho_{j 2}$ are the values of PC1 and PC2, respectively, for the environment of order $\mathrm{j}$; and $\varepsilon_{i j}$ is the error associated to the model of the $\mathrm{i}^{\text {th }}$ genóipo and $\mathrm{j}^{\text {th }}$ environment (Yan et al., 2000). This analysis was performed using the GGEGui package implemented in the R software (R Development Core Team, 2014).

\section{RESULTS AND DISCUSSION}

All effects were significant $(\mathrm{P} \leq 0.05)$ on joint analysis (Table 2$)$, indicating at least a significant orthogonal contrast between the environment effects and differential responses of the genotypes in comparison. This can be confirmed by observing the soil and climatic features 
of each environment (Table 1), which differ in altitude, latitude, and longitude, and by their climates, including rainfall and temperature. Similar results were obtained by Almeida Filho et al. (2010, 2014), who found significant differences in the G and E effects, and in the GE interaction, when evaluating grain sorghum genotypes in multienvironment trials in Brazil. The existence of a significant GE interaction for grain yield justifies the use of adaptability and stability analyzes to identify stable genotypes that are adapted to environments of interest.

Table 2. Summary of joint analysis of variance of 25 sorghum genotypes evaluated in seven environments
during the second harvest of 2011 .
\begin{tabular}{l|c|c}
\hline Sources of variation & Degrees of freedom & Mean square \\
\hline Blocks/Environments & 14 & $2,920,365.03$ \\
\hline Genotypes (G) & 24 & $1,766,757.31^{*}$ \\
\hline Environments (E) & 6 & $109,611,882.64^{*}$ \\
\hline GE & 144 & $890,609.41^{*}$ \\
\hline Error & 336 & $401,634.16^{*}$ \\
\hline Coefficient of variation (\%) & - & 14.38 \\
\hline
\end{tabular}

*Significant at $1 \%$ probability by the $\mathrm{F}$ test.

A polygon was generated that connected the genotypes BRS 308 (G24), 307091 (G9), 307509 (G16), 307131 (G11), and 1G282 (G23), which are farther away from the Biplot origin (Figure 1). These genotypes have the largest vectors in each respective direction; the vector of length and direction is the extension of the genotype response for the tested environments. All other genotypes are contained within the polygon and have smaller vectors, i.e., they are less sensitive compared to the interaction with the environments of each sector (Yan and Rajcan, 2002). The vectors from the biplot center $(0,0)$, which are perpendicular to the sides of the polygon, divided the graph into five sectors. Similar results were observed by Mattos et al. (2013) who observed graphs divided into six sectors when assessing the stem productivity of sugarcane genotypes using GE biplot methodology.

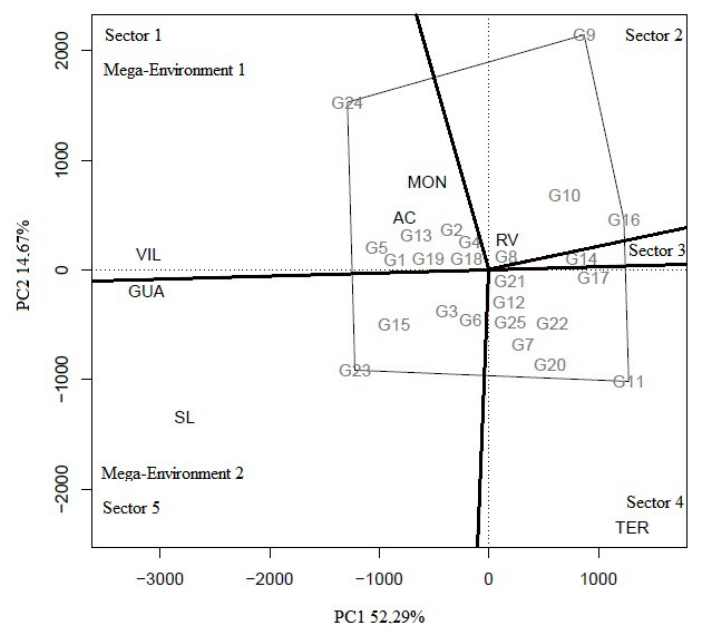

Figure 1. Sectors and mega-environments obtained by the genotype main effects + genotype environment interaction (GGE) biplot model for grain yield of 25 sorghum genotypes evaluated in seven environments during the second harvest of 2011. AC = Água Comprida-MG; GUA = Guaíra-SP; MON = Montividiu-GO; RV = Rio Verde-GO; SL = Sete Lagoas-MG; TER = Teresina-PI; VIL = Vilhena-RO. 
Mega-environments are sectors that contain one or more environment. The GGE biplot polygon (Figure 1) grouped the sites Água Comprida-MG (AC), Montividiu-GO (MON), and Vilhena-RO (VIL) into Mega-Environment 1, where the genotype BRS 308 (G24), present at the vertex, had the highest mean for grain yield in these sites, in addition to second highest mean among the genotypes (Table 3). The sites Guaíra-SP (GUA) and Sete Lagoas-MG (SL) formed Mega-Environment 2, with genotype 1G282 (G23) at the vertex being the most productive at SL, with the highest mean among all genotypes.

The genotypes that compose one sector that has no environment are considered unfavorable to the tested environments, especially by low yield (Karimizadeh et al., 2013). In this way, individuals located at sectors comprised by polygon are also unfavorable to the recommendation. In this context, with the exception of genotype 307401 (G14) in sector 3 of Figure 1, we infer that the other genotypes possess some specific adaptation and should be carefully evaluated in order to obtain better recommendations.

Grain yield and genotype stability were evaluated from the coordination of the medium environment (CAE). The ordered CAE is represented by two axes facing in opposite directions from the biplot origin. The greater the genotype projection in the axis of the CAE ordinate, the greater the instability of genotypes, thus representing a greater interaction with the environments (Yang et al. 2009). In this regard, the genotypes 1G282 (G23) and BRS 308 (G24) are highlighted by phenotypic stability (Figure 2), as well as having a high mean yield over the environments (Table 3). On the other hand, genotype 307091 (G9) could be discarded as having high instability and low average yield over the environments.

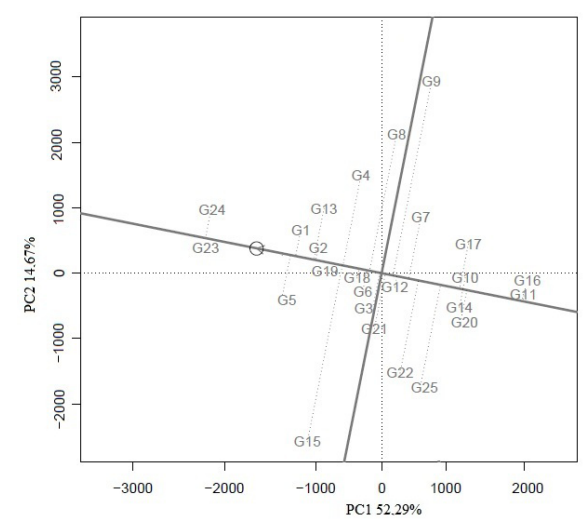

Figure 2. Mean versus stability according to the GGE biplot model for grain yield of 25 sorghum genotypes evaluated in seven environments during the second harvest of 2011.

The vector length on the axis of the ideal environment, plotted on the abscissa of the $\mathrm{CAE}$, is an estimate of the importance of the genotype main effect (L) versus the main effect of the GE interaction (Yan and Rajcan, 2002). The higher the PC1, more important is the G effect, consequently more significant is the selection based on the mean of this genotype. We observed a significant response for selection based on the mean performance of the genotypes 1G282 (G23) and BRS 308 (G24) (Figure 2).

An ideal genotype should have a mean grain yield that is consistently high in all environments studied. This ideal genotype is graphically defined by the longest vector in PC1 and PC2 without projections, represented by the arrow in the center of concentric circles (Yan 
and Rajcan, 2002). Although this genotype is more of a representative model, it is used as a reference for genotype evaluation. Therefore, we highlight the genotypes 1G282 (G23) and BRS 308 (G24), since they are closest to the ideal in terms of high grain yield and phenotypic stability (Figure 3).

Table 3. Mean grain yield ( $\mathrm{kg} / \mathrm{ha})$ of 25 sorghum genotypes for each tested environment and overall mean of the genotype and environments.

\begin{tabular}{|c|c|c|c|c|c|c|c|c|c|}
\hline Code & Genotype & $\mathrm{AC}$ & GUA & MON & RV & SL & TER & VIL & Mean \\
\hline G1 & BRS 380 & 4014.83 & 4298.70 & 3553.13 & 6207.66 & 4722.61 & 6121.16 & 4367.13 & 4755.03 \\
\hline G2 & 144013 & 4179.85 & 3545.29 & 3808.25 & 5679.83 & 4838.23 & 5846.33 & 3735.68 & 4519.06 \\
\hline G3 & 307001 & 3749.66 & 4793.62 & 2795.82 & 5965.37 & 4499.54 & 6232.22 & 2878.93 & 4416.45 \\
\hline G4 & 307047 & 3871.57 & 4362.79 & 3746.48 & 6403.13 & 4076.84 & 6304.68 & 3460.47 & 4603.71 \\
\hline G5 & 307061 & 4271.11 & 4658.15 & 3036.16 & 5744.54 & 4832.06 & 5863.60 & 4118.71 & 4646.33 \\
\hline G6 & 307063 & 4171.95 & 3882.61 & 2959.91 & 5880.17 & 4407.07 & 6561.79 & 3624.58 & 4498.30 \\
\hline G7 & 307071 & 3734.29 & 4292.96 & 3825.44 & 6307.92 & 4145.86 & 7149.56 & 2520.99 & 4568.14 \\
\hline G8 & 307087 & 3710.73 & 3848.66 & 3982.91 & 6717.03 & 3861.10 & 6637.93 & 3494.91 & 4607.61 \\
\hline G9 & 307091 & 3929.81 & 2658.89 & 4070.35 & 6065.08 & 3009.38 & 5183.39 & 2719.09 & 3948.00 \\
\hline G10 & 307095 & 3344.87 & 4079.86 & 2920.06 & 5698.54 & 3204.07 & 5844.80 & 2215.48 & 3901.10 \\
\hline G11 & 307131 & 3689.20 & 2586.90 & 2914.65 & 6014.44 & 3528.57 & 7622.18 & 2508.87 & 4123.54 \\
\hline G12 & 307341 & 3789.73 & 4071.33 & 2905.04 & 6027.37 & 3814.80 & 6689.55 & 3788.74 & 4440.94 \\
\hline G13 & BRS 373 & 4168.51 & 4439.93 & 2776.73 & 6400.75 & 4163.82 & 5882.02 & 4166.22 & 4571.14 \\
\hline G14 & 307401 & 4023.68 & 3150.88 & 2393.94 & 5633.66 & 2919.78 & 6718.42 & 3477.89 & 4045.46 \\
\hline G15 & 307421 & 3565.75 & 4721.50 & 3157.69 & 5066.58 & 4960.38 & 6170.77 & 4247.98 & 4555.81 \\
\hline G16 & 307509 & 3082.68 & 2902.83 & 3211.57 & 5659.61 & 2864.25 & 6421.76 & 2476.36 & 3802.72 \\
\hline G17 & 307511 & 4104.75 & 3067.82 & 2804.19 & 5919.77 & 3311.36 & 6725.22 & 2645.89 & 4082.71 \\
\hline G18 & 307541 & 3770.84 & 4391.56 & 2579.13 & 6195.92 & 4156.58 & 6049.61 & 4010.28 & 4450.56 \\
\hline G19 & 307561 & 3995.67 & 4469.44 & 3008.56 & 6003.95 & 4139.83 & 6242.81 & 4141.80 & 4571.72 \\
\hline G20 & 307651 & 3406.90 & 3592.79 & 3187.22 & 5943.46 & 3967.70 & 7192.40 & 2899.22 & 4312.81 \\
\hline G21 & 307671 & 3843.91 & 3338.97 & 3786.06 & 5336.16 & 4555.23 & 6514.21 & 3490.78 & 4409.33 \\
\hline G22 & 307689 & 3897.82 & 2982.80 & 3399.12 & 5184.41 & 4216.36 & 6919.81 & 3809.56 & 4344.27 \\
\hline G23 & $1 \mathrm{G} 282$ & 3880.31 & 5012.35 & 3753.74 & 5600.24 & 5575.03 & 6553.11 & 4384.84 & 4965.66 \\
\hline G24 & BRS 308 & 4410.34 & 5112.08 & 4071.53 & 5652.82 & 4242.48 & 5086.83 & 4858.74 & 4776.40 \\
\hline G25 & BRS 330 & 2945.17 & 3820.46 & 2960.79 & 5730.39 & 4436.20 & 6349.22 & 3472.94 & 4245.02 \\
\hline \multicolumn{2}{|l|}{ Mean } & 3822.16 & 3923.33 & 3264.34 & 5881.55 & 4097.97 & 6355.34 & 3500.64 & 4406.47 \\
\hline
\end{tabular}

$\mathrm{AC}=$ Água Comprida-MG; GUA = Guairá-SP; MON = Montividiu-GO; RV = Rio Verde-GO; SL = Sete LagoasMG; TER = Teresina-PI; VIL = Vilhena-RO.

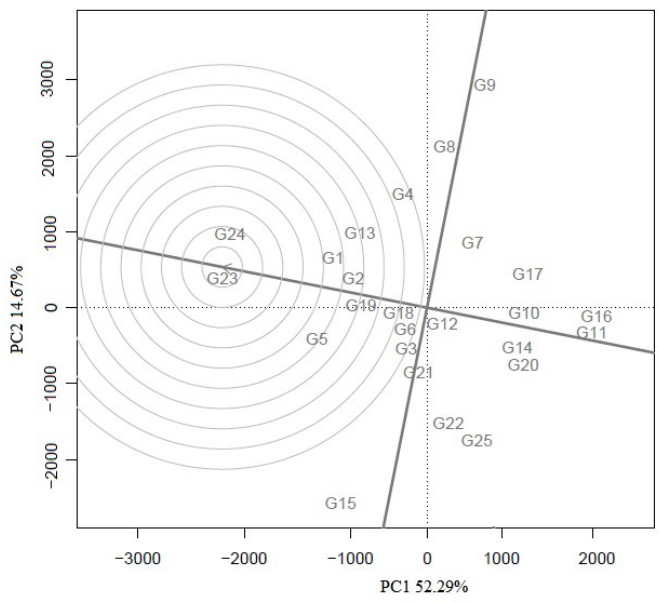

Figure 3. Classification of 25 sorghum genotypes according to the GGE biplot model based on their grain yield evaluated in seven environments during the second harvest of 2011. 
Figure 4 shows the relationship between yield and the stability of the vector viewpoint of environments, where environments are connected by vectors with the biplot origin. In environments with small vectors, the yield stability is high (Yang et al., 2009). Thus, the difference between the mean yield of each genotype was lower in MON, i.e., this environment contributed less to the GE interaction. On the other hand, the environments SL, VIL, and Rio Verde-GO were the main contributors to GE interaction.

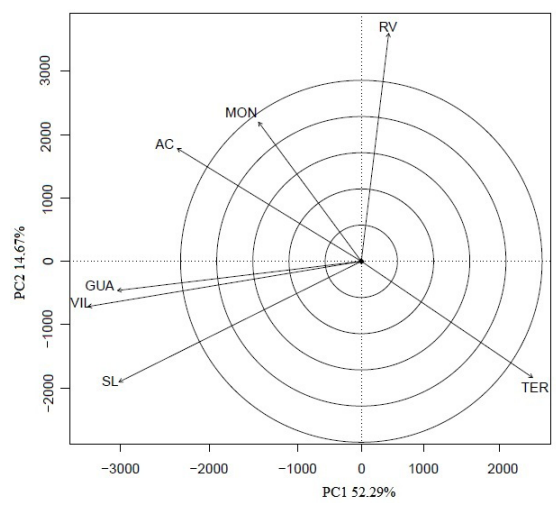

Figure 4. Relationship between environments obtained by the GGE biplot model based on grain yield of 25 sorghum genotypes evaluated during the second harvest of 2011. AC = Água Comprida-MG; GUA = Guairá-SP; $\mathrm{MON}=$ Montividiu-GO; RV = Rio Verde-GO; $\mathrm{SL}=$ Sete Lagoas-MG; TER = Teresina-PI; VIL = Vilhena-RO.

For Yang et al. (2009), ideal environments should have a high score for PC1 (greater power of discrimination in terms of genotype main effects) and a zero score for PC2 (most representative of all other environments). In the same way as the ideal genotype, the ideal environment is only an estimate and serves as a reference for the choice of site for multienvironment testing. Thus, the environments VIL and GUA are those with the greatest capacity for discriminating genotypes, favoring the selection of superior genotypes.

In conclusion, the GGE biplot methodology identified two groups of environments, the first composed of AC, MON, and VIL and the second of GUA and SL. The BRS 308 and 1G282 genotypes have high grain yield, adaptability, and phenotypic stability and are thus indicated for cultivation in the first and second groups of environments, respectively.

\section{Conflicts of interest}

The authors declare no conflict of interest.

\section{ACKNOWLEDGMENTS}

Research supported by Embrapa Milho e Sorgo and Conselho Nacional de Desenvolvimento Científico e Tecnológico (CNPq).

\section{REFERENCES}

Almeida Filho JE, Tardin FD, Souza AS, Godinho VPC, et al. (2010). Desempenho agronômico e estabilidade fenotípica de híbridos de sorgo granífero. Rev. Bras. Mil. Sor. 9: 51-64. 
Almeida Filho JE, Tardin FD, Daher RF, Barbé TC, et al. (2014). Stability and adaptability of grain sorghum hybrids in the off-season. Genet. Mol. Res. 13: 7626-7635.http://dx.doi.org/10.4238/2014.March.24.24

Banzatto DA and Kronka SN (2006). Experimentação Agrícola. 4 ed., FUNEP, Jaboticabal.

Cruz CD, Carneiro PCS and Regazzi AJ (2014). Modelos biométricos aplicados ao melhoramento genético. 3.ed. Editora UFV, Viçosa.

Karimizadeh R, Mohammadi M, Sabaghni N, Mahmoodi AA, et al. (2013). GGE biplot analysis of yield stability in multienvironment trials of lentil genotypes under rainfed condition. Not. Sci. Biol. 5: 256-262.

Mattos PHC, Oliveira RA, Bespalhok Filho C, Daros E, et al. (2013). Evaluation of sugarcane genotypes and production environments in Paraná by GGE biplot and AMMI analysis. Crop Breed. Appl. Biotechnol. 13: 83-90. http://dx.doi. org/10.1590/S1984-70332013000100010

Miranda GV, Souza LV, Guimarães LJM, Namorato H, et al. (2009). Multivariate analyses of genotype x environment interaction of popcorn. Pesquisa Agropecu. Bras. 44: 45-50. http://dx.doi.org/10.1590/S0100-204X2009000100007

R Development Core Team (2014). R: a language and environment for statistical computing. Vienna: R Foundation for Statistical Computing, 2014. Available at [http://www.R-project.org].

Ramalho MAP, Abreu A, Santos JB and Nunes JAR (2012). Aplicações da Genética Quantitativa no Melhoramento de Plantas Autógamas. UFLA, Lavras.

Yan W and Rajcan I (2002). Biplot evaluation of test sites and trait relations of soybean in Ontario. Crop Sci. 42: 11-20. http://dx.doi.org/10.2135/cropsci2002.0011

Yan W, Hunt LA, Sheng QL and Szlavnics Z (2000). Cultivar evaluation and mega-environment investigation based on the GGE Biplot. Crop Sci. 40: 597-605. http://dx.doi.org/10.2135/cropsci2000.403597x

Yang RC, Crossa J, Cornelius PL and Burgueño J (2009). Biplot analysis of genotype $\mathrm{x}$ environment interaction: proceed with caution. Crop Sci. 49: 1564-1576. http://dx.doi.org/10.2135/cropsci2008.11.0665

Yates F and Cochran WG (1938). The analysis of group of experiments. J. Agric. Sci. 28: 556-580. http://dx.doi. org $/ 10.1017 / \mathrm{S} 0021859600050978$ 